\title{
THE INFLUENCE OF FLAXSEED ON THE BODY WEIGHT OF WISTAR OVARIOCTOMIZED RATS
}

\author{
INFLUÊNCIA DA SEMENTE DE LINHAÇA SOBRE O PESO RELATIVO \\ CORPORAL DE RATAS WISTAR OOFORECTOMIZADAS
}

\author{
Thais Rezende Bessa Guerra ${ }^{\mathrm{a}^{*}}$ \\ atcrezende@ig.com.br \\ "Universidade Federal Fluminense - Niterói (RJ), Brasil
}

Data de entrega do artigo: 06/11/2013

Data de aceite do artigo: 17/04/2014

\section{ABSTRACT}

Objectives: To evaluate the influence of flaxseed for a long period of time and its hormonal effects of weight loss in castrated rats. Methods: We used 21 Wistar rats that underwent bilateral oophorectomy for induction of menopause, randomly divided into three groups: control group (CG) $(n=7)$, which received a diet based on casein 10 percent; flaxseed group, that received a diet based on casein plus 25 percent of flaxseed $(\mathrm{FG})(\mathrm{n}=7)$; and modified control group, that received a diet based on modified casein 10 percent and with addition of lipid and fibers (CGM) $(n=7)$. All diets were prepared according to the recommendations of the AIN 93, the animals were kept under controlled temperature $\left(22^{\circ} \mathrm{C} \pm\right.$ $2^{\circ} \mathrm{C}$ ) and adequate lighting (light/dark cycle of 12 to 12 hours). The animals received food and water (ad libitum). The rats were anesthetized with Thiopentax ${ }^{\oplus}$ for blood collection by cardiac puncture for the determination of $17 \beta$-estradiol and collection of tissues (liver, bladder and uterus). Data was applied to statistical analysis using the nonparametric Kruskal-Wallis test and applied post hoc Mann-Whitney U for two by two comparison through Software S-Plus version 8.0, with the level of 0.05 for the significant differences. Results: The results show that the concentration of $17 \beta$-estradiol of FG was 40.2 percent higher than the CG and 25.77 percent higher than CGM, suggesting the estrogenic action of the flaxseed. In the body weight of the animals there were significant differences, suggesting a greater weight of the GC. There were no significant differences in the relative liver $(\mathrm{p}=0.2405)$ and bladder $(\mathrm{p}=0.7734)$ weight between the groups, andt there was no significant difference in the relative weight of the uterus $(\mathrm{p}=0.7922)$ between the casein and flaxseed groups. Conclusion: The consumption of 25 percent of flaxseed during menopause influenced on body weight, suggesting a phytoestrogen action in the consumption of seeds during the physiological stage.

Keywords: flaxseed, hormonal effects, body weight, ovariotomy.

\section{RESUMO}

Objetivos: Avaliar a influência da semente de linhaça por um longo período de tempo e seus efeitos hormonais sobre o peso relativo corporal em ratas ooforectomizadas. Material e métodos: Foram utilizadas 21 ratas Wistar, submetidas à ooforectomia bilateral para indução da menopausa, sorteadas aleatoriamente em três grupos: Grupo Controle $(\mathrm{GC})(\mathrm{n}=7)$, que receberam raçáo à base de caseína $10 \%$; o Grupo Linhaça $(\mathrm{GL})(\mathrm{n}=7)$, que recebeu ração à base de linhaça 25\%; e o Grupo Controle Modificado $(\mathrm{GCM})(\mathrm{n}=7)$, que recebeu ração à base de caseína modificada $10 \%$ e adição de lipídio e fibras. Todas as raçôes foram elaboradas segundo as recomendaçôes da AIN 93, os animais mantidos em ambiente com temperatura controlada $\left(22^{\circ} \mathrm{C} \pm 2^{\circ} \mathrm{C}\right)$ e iluminaçáo adequada (ciclo claro/escuro de $12 \mathrm{em} 12$ horas). Os animais receberam ração e água ( $a d$ libitum). As ratas foram anestesiadas com Thiopentax ${ }^{\oplus}$ para a coleta do 
sangue por punção cardíaca, para determinação do $17 \beta$-Estradiol. Foi realizada coleta dos tecidos: fígado, bexiga e útero para determinação do peso relativo corporal. Aos dados foram aplicados a análise estatística, utilizando o teste não paramétrico de Kruskal-Wallis e aplicado teste post hoc $U$ de Mann-Whitney para comparação dois a dois por meio do Software S-Plus versáo 8.0, com o nível de 0,05 para as diferenças significativas. Resultados: Os resultados mostram que a concentração do $17 \beta$-estradiol do GL foi 40,2\% superior ao GC e 25,77\% maior que GCM, sugerindo a ação estrogênica da semente de linhaça. No peso relativo corporal dos animais houve diferença significativa, sugerindo maior peso para o GC. Náo houve diferença significante no peso relativo do fígado $(\mathrm{p}=0.2405)$ e bexiga $(\mathrm{p}=0.7734)$ entre os grupos. Já no peso relativo do útero $(\mathrm{p}=0.7922)$, não houve diferença significativa entre o grupo caseína e linhaça. Conclusão: Conclui-se que o consumo de $25 \%$ de semente de linhaça durante a menopausa influenciou no peso relativo corporal, sugerindo açáo fitoestrógena da semente durante a fase fisiológica.

Keywords: flaxseed, hormonal effects, body weight, ovariotomy.

\section{INTRODUCTION}

The flaxseed (Linum usitatissinum) is an oilseed often used as a food supplement, and it is a source of soluble and insoluble fiber, protein (providing $20 \%$ of its composition), $41 \%$ fat, $6 \%$ carbohydrate and $4 \%$ of waste (1). This seed is considered a phytoestrogen, which produces metabolic and physiological benefits (2). The consumption of flaxseed has been beneficial to health in different conditions, such as cardiovascular disease prevention, reduction of cholesterol and triglycerides (4), minimizing the symptoms of menopause, exerting a beneficial effect on obesity (5), preventing osteoporosis (6) and certain types of breast and uterus cancer that are developed under the influence of hormones (7).

The flaxseed is recognized as a major food source of lignans $(52.7 \mathrm{mg} / 100 \mathrm{~g}$ seed flour $)$ on its diglucosidic $(8,9)$ compounds with similar chemical structure to estrogen (10), specifically the Secoisolaricirecinol Diglucoside (SDG) (figure 1) that after been absorbed through the gastrointestinal tract and distributed to the tissues have the ability to bind to estrogen receptors (ER $\alpha$ and $\beta)(11,12)$ acting as agonists or antagonists, depending on the amount of it in the body (13). In premenopausal stages these lignans act as antagonists, reducing the action of this hormone (14). In post-menopause and menopause stages, when estrogen levels are naturally ceased, the lignans act as agonists, similar to the effects of estrogens, although less potent (15).

Among the estrogens, estradiol is the most important and abundant in the blood circulation (16), but when bound to albumin it has the feature of decoupling quickly as it is released in the active form in various tissues with estrogen receptors $(17,18)$

Estrogen receptors have high sensitivity and affinity for a specific hormone estrogen produced in the body. Therefore, extremely low concentrations of hormone produce a particular effect, inducing a natural response. However, these hormone receptors bind to other substances such as phytoestrogens, even at very low concentrations, and are capable of generating purposes, thus provoking responses agonists or antagonists (19).
Figure 1: Chemical structural similarity between Estradiol and Secoisolariciresinol Diglucoside

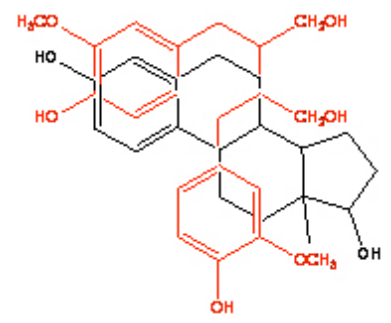

Hu et al., 2007.

Despite the benefits attributed to the consumption of flaxseed, its use in stages of menopause and post menopause has sparked interest in the scientific community. The association of flaxseed and menopause remains uncertain because of the prevalence of central obesity and overweight $(20,21)$ among female population in this physiological stage (22), due to the complex physiological and psychological factors involved (23), such as the reduction of lean mass (22), a reduction in the metabolism that alters the hormonal balance and energy expenditure (24).

Little is known about consumption of seed exclusively at menopause, because the results of studies on the subject were very contradictory, varying greatly depending on the concentration of flaxseed that was used. This study aims to observe the effects of consuming 25 percent of flaxseed at menopause for a long period of time and its hormonal effects on weight loss of ovariectomized female rats.

\section{Materials and methods}

\section{Ethical aspects}

This project was approved by the Ethics Committee in Research of Hospital Antônio Pedro/UFF, Protocol 
188/06. In order to be able to develop the assay, this project was approved by the Ethics Committee for Animal Research (NAL)/UFF, under the Protocol 00103-09 and followed the protocol standards set out in Guide for Care and Use of Laboratory Animals published by U.S. National Institutes of Walt. This project was conducted within the ethical principles of Good Practices of the Brazilian College of Animal Experimentation (COBEA).

\section{Delineament Experiment}

In the biological assay of 180 days, we used 21 female animals, newly weaned Wistar (Rattus norvegicus, Albinus variety, order Rodentia mammalia, family Muridae) from the colony of the Laboratory of Experimental Nutrition of the Department of Nutrition and Dietetics in the School of Nutrition, at the Fluminense Federal University, in Niterói, RJ, Brazil. After the weaning in approximately 21 days of life, the animals received a commercial diet (Cr-1 Nuvilab Autoclavable-Nuvital ${ }^{\oplus}$ ) until they could be considered adults. In 90 days, the necessary period of time for a normal animal to reach adulthood after his birth, the rats underwent bilateral ovariectomy to induce an early menopause, according to (25). After surgery, the animals were fed commercial for 30 days. After this period, which was the time required in order to achieve a status of menopause, the animals were randomly selected and divided into groups, which will be detailed below.

At the end of 180 days of experiments, the animals were anesthetized with thiopental $(0.15 \mathrm{ml} / 100 \mathrm{~g}$, intraperitoneal) in order to allow the researchers to perform the blood collection by cardiac puncture for determination of $17 \beta$-estradiol. For this procedure it was used a hypodermic needle into Vacutainer tubes with capacity of $10 \mathrm{ml}$. The tubes containing blood were centrifuged (Sigma) for 30 minutes at 3500 revolutions per minute (RPM) (26) to obtain the serum and after it the tubes were stored in the freezer-20 for determination of the serum $17 \beta$-estradiol in animals. The tissues were collected, weighed on a precision scale and stored in nitrogen at $-80^{\circ} \mathrm{C}$.

Throughout the test, the animals were kept in plastic cages in an environment with constant temperature (22 ${ }^{\circ} \mathrm{C} \pm 2{ }^{\circ} \mathrm{C}$ ) and adequate lighting (light/dark cycle of 12 to 12 hours). Water was offered (ad libitum), and the diet, weight and feed intake were recorded every two days.

\section{Experimental groups and diets}

The animals were divided into groups $(\mathrm{n}=7)$ : a control group (CG), which was fed with a casein diet with
10 percent of protein, 5 percent of fiber, and 7 percent of oil; the Flaxseed Group (FG), which was fed with a casein diet with 10 percent of protein, plus 25 percent of flaxseed meal, 7 percent of fiber and 11 percent of lipid; and Modified Control Group (MCG), which was fed with a casein diet, with 10 percent of protein, 7 percent of fiber and 11 percent of oil.

The insertion of the Modified Control Group was made by the chemical composition present in flaxseed, which is a good source of lipids and has high fiber content. In order to obtain parameters for comparison of diets, we aimed to increase the concentrations of their constituents so that they would present similar chemical compositions to their compositions.

To obtain the flour milling of flaxseed the process was performed on fresh seed mill Fritsch Pulverisette, that held the weight of flaxseed meal resulting from this process they were bagged, sealed and stored in refrigerator $\left(4^{\circ} \mathrm{C}\right)$ until used for the manufacture of ration. All diets were prepared according to the density (from lightest to heaviest) of the ingredients in pet food. Then they were mixed in the container, and subsequently taken to the mixer for homogenisation. After that, the pellets were placed in stainless steel trays and placed in an oven $\left(55-60{ }^{\circ} \mathrm{C}\right)$ for 24 hours and after identification, the ration resulting from this process was refrigerated until use.

All diets were added to the mixture of minerals and vitamins, according to rules of the Laboratory of Animal Diets on Committee, of 1979, modified in accordance with the recommendations of the American Institute of Nutrition-AIN 93G.

\section{Methods}

\section{Surgical: Bilateral Oophorectomy}

This procedure followed the standards of vivisection of animals set by the Brazilian College of Animal Experimentation (COBEA) under the Law no 6638 of May 8, 1979. The surgical procedures were performed in the morning. Before the procedure, the rats underwent eight hours of fasting. We used intramuscular anesthesia with ketamine (Cristalia ${ }^{\oplus}-100 \mathrm{mg} / \mathrm{kg}$ the animal intramuscule) and xylazine (Anasedanâ Vetbrands ${ }^{\oplus}$ - $20 \mathrm{mg} / \mathrm{kg}$ of animal intramuscule). Moreover, the animals received analgesia with tramadol (TramaLive Teuto ${ }^{\oplus}-5 \mathrm{mg} / \mathrm{Kg}$ the animal intramuscule), which was injected 1-2 minutes after surgical incision in order to minimize the suffering of rats in the postoperative period (Laboratory Animals published by U.S. National Institutes of Walt). 
The animals were placed in a supine. After trichotomy, antisepsis was performed with iodine alcohol. A bilateral oophorectomy was performed through a midline incision of approximately $4 \mathrm{~cm}$ in length. After opening the abdominal cavity, the ovaries were identified and their heel ends were clipped and ligated using catgut $3 / 0$ simple.

The ovaries were then removed and the ligature were reviewed. A raffia in the peritoneum was performed and also a with a $3 / 0$ chromed catgut. The skin was closed with separated mononylon $4 / 0$ according to the methodology described by Biondo-Simóes et al. (25).

\section{Biochemical Analysis: Hormonal}

The animals were anesthetized with intraperitoneal thiopental (Thiopentax ${ }^{\oplus} \mathrm{ml} / 100 \mathrm{~g} 0.15 \mathrm{pc}$, intraperitoneal) and the blood was collected by cardiac puncture using a hypodermic needle and vacuum tubes (Vacueete) with capacity of $10 \mathrm{ml}$. The blood collected in tubes was centrifuged in a centrifuge (Sigma ${ }^{\circ}$ ) for 30 minutes at $3500 \mathrm{rpm}$ (revolutions per minute) (26) to obtain the serum. This was separated and fractionated in eppendorffs, one of them for determining concentrations of $17 \beta$-estradiol, and stored in freezer at $-20^{\circ} \mathrm{C}$.

The hormonal assays were determined by specific radioimmunoassay for each hormone, using the biochemical kit from Diagnostic Products Corporation - CPS ๑, Tortelly Carlos Municipal Hospital, in Niterói, in a VITALAB Selectra ${ }^{\circ}$ apparatus.

\section{Biological Analysis: Determination of the relative weight and body tissues (liver, bladder and uterus).}

Before all animals were weighed, we made sure they were unfed, in order to remove the organs. We used forceps and scissors for the procedures, and they were weighed on an analytical Bosch brand balance, model S2000, accurate to $0.0001 \mathrm{~g}$.

This procedure was performed to calculate the relative weight of tissues and relative body weight, which calculated the weight of each organ and divided it by the body weight. The result was multiplied by 100 , being indicated in percentage (\%).

\section{Statistical Analysis}

The results displayed below include mean and standard deviation (SD). The obtained results were submitted to the Kruskal-Wallis test for an analysis of variance.
When a significant difference was detected, the MannWhitney $U$ test for comparison of two by two was applied post hoc.

These statistical analysis were performed by the software S-Plus version 8.0, with a level of significance of 0.05 .

\section{Results}

Table 1: Composition of experimental diets (g/100g).

\begin{tabular}{|c|c|c|c|}
\hline $\begin{array}{c}\text { Groups } \\
\text { Ingredients }\end{array}$ & CG & CGM & FG \\
\hline Flaxseed $^{1}$ & - & - & 25,00 \\
\hline Casein $^{2}$ & 10,87 & 10,87 & 5,43 \\
\hline $\mathrm{Starch}^{3}$ & 62,08 & 59,08 & 54,52 \\
\hline Sugar $^{4}$ & 10,00 & 10,00 & 10,00 \\
\hline Minerals $\operatorname{mix}^{1}$ & 3,50 & 3,50 & 3,50 \\
\hline Viitamins $\operatorname{mix}^{1}$ & 1,00 & 1,00 & 1,00 \\
\hline $\mathrm{Oil}^{5}$ & 7,00 & 11,00 & - \\
\hline Celullose ${ }^{6}$ & 5,00 & 7,00 & - \\
\hline B-Choline ${ }^{1}$ & 0,25 & 0,25 & 0,25 \\
\hline Cystine $^{1}$ & 0,30 & 0,30 & 0,30 \\
\hline Total & 100,00 & 100,00 & 100,00 \\
\hline
\end{tabular}

Note: The CG was fed with a casein diet with 10 percent of protein, 5 percent of fiber and 7 percent of oil, the MCG was fed with a casein diet with 10 percent of protein, 7 percent of fiber and 11 percent of oil, and the FG was fed with a casein diet with 10 percent of protein supplemented with 25 percent of flaxseed meal, 7 percent of fiber and 11 percent of oil.

Table 2: Approximate chemical composition of experimental diets

\begin{tabular}{cccc}
\hline $\begin{array}{c}\text { Chemical } \\
\text { composition } \\
(\mathbf{g} / \mathbf{1 0 0 g})\end{array}$ & Casein & $\begin{array}{c}\text { Casein } \\
\text { modification }\end{array}$ & Flaxseed \\
\hline $\begin{array}{c}\text { Moisture \% } \\
\text { Lipids \% }\end{array}$ & $2,23 \pm 0,04$ & $2,35 \pm 0,04$ & $1,95 \pm 0,08$ \\
ash \% & $4,27 \pm 0,02$ & $4,47 \pm 0,07$ & $4,42 \pm 0,07$ \\
Protein \% & $9,77 \pm 0,45$ & $9,75 \pm 0,45$ & $10,18 \pm 1,06$ \\
Fibers \% & $5,00 \pm 0,34$ & $6,70 \pm 0,52$ & $6,98 \pm 0,47$ \\
Carboydrate \% & 70,91 & 64,92 & 64,77 \\
BEV* & 392,83 & 379,8 & 379,8
\end{tabular}

* BEV= Baseline Energy Value

In order to study the use of flaxseed, it is supplemented in experimental diets. There is still a consensus in the literature regarding the daily recommendation of this seed, therefore, we used about 25 percent of it in the ration. We chose to use the seed in the form of flour because it allows a better use of its functional properties. 


\section{Determination of $17 \beta$-estradiol}

The concentration of $17 \beta$-estradiol FG (48.7 \pm $12.31 \mathrm{pg} / \mathrm{dl})$ was 40.2 percent higher than in CG $(29.0$ $\pm 5.4 \mathrm{pg} / \mathrm{dl})$ and $25.77 \%$ higher than in MCG $(36,0 \pm$ $5.60 \mathrm{pg} / \mathrm{dl}$ ), suggesting the estrogenic action of flaxseed $(\mathrm{P}<0.0012)$.

\section{Determination of relative body weight}

There were significant differences in the body weight in the groups on flaxseed and casein, that had a higher value $(p<0.0013)$. In the Modified Casein Group the higher value $(p<0.002)$ had no significant difference in comparison to the other groups. (Table 3 ).

\section{Determining the relative weight of tissues}

There were significant differences in relative liver weight $(\mathrm{p}<0.2)$ and in the relative weight of the bladder $(\mathrm{p}<0.5)$ between the groups; the casein group presented heavier weights (Table 4 and Chart 2). The weight of the uterus $(\mathrm{p}<0.9)$ did not differ between the casein and flaxseed group, but the modified casein and flaxseed group showed significant differences (Table 4 and Chart 3).

Table 3: Relative body weight of the bladder, uterus and liver and serum estradiol values.

\begin{tabular}{cccc}
\hline & CG & MCG & FG \\
\hline $\begin{array}{c}\text { Relative Weight } \\
\text { body (g) }\end{array}$ & $294 \pm 33.1$ & $339.5 \pm 24.6$ & $275.75 \pm 33.9$ \\
$\begin{array}{c}\text { Relative Weight of } \\
\text { the bladder (mg) }\end{array}$ & $0.01 \pm 0.003$ & $0.01 \pm 0.002$ & $0.01 \pm 0.013$ \\
$\begin{array}{c}\text { Relative Weight if } \\
\text { the uterus (mg) }\end{array}$ & $0.01 \pm 0.01$ & $0.02 \pm 0.06$ & $0.02 \pm 0.06$ \\
$\begin{array}{c}\text { Relative Weight of } \\
\text { the liver (mg) }\end{array}$ & $0.06 \pm 0.01$ & $0.07 \pm 0.025$ & $0.08 \pm 0.01$ \\
\begin{tabular}{c} 
Estradiol $(\mathrm{pg} / \mathrm{dl})$ \\
\hline
\end{tabular} & $29,0 \pm 5,4$ & $36,0 \pm 5,60$ & $48,7 \pm 12,31$ \\
\hline
\end{tabular}

Values are expressed as $\pm \mathrm{SD}$. There are statistical differences in the groups, measured by the Mann-Whitney test (p>0.05). FG: Flaxseed Group, CG: Control Group, CMCG: Modified Control Group.

\section{Discussion}

The dietary fibers are able to accelerate intestinal transit, and promote satiety, helping to reduce the body weight $(26,27,28,29,30)$, among other functions. In this study, we observed that flaxseed has a high concentration of soluble and insoluble fibers, suggesting that variation of weight in the FG is presented below the CG, since the fibers are able to help in the reduction of the body weight $(31,32,33)$. Moreover, the presence of phytates in this seed can affect the bio-utilization of nutrients in the ration to which was added, which may be diminishing the weight of animals (34). Animal studies that used flaxseed also found lower weight gain in those who consumed the seed. (35).

Several authors (36) conducted studies with estradiol-treated ovariectomized rats that gained less weight, while animals receiving progesterone hormone replacement therapy lost weight. Moreover, similar results to the ones in our study (37), did not find weight alterations in the tissues after feeding rats with flaxseed or defatted flaxseed for eight weeks.

There is a close relation between the action of phytoestrogens in the flaxseed and lower relative body weight gain and menopause, suggesting that the influence of seed increased energy consumption and consequently lowered the body weight. The estrogenic action, specifically the SDG (Figure 1), in this seed significantly increased serum levels of $17 \beta$-estradiol, influenced by an interaction of hormone receptors in animal organism (13). This is an extremely important observation, since the majority of circulating estradiol binds to estrogen receptors, including the phytoestrogens.

It was found that an increase in hormone levels of FG could be associated with high concentration of lipid present in this diet, which stimulates the synthesis of this hormone in other ways besides in the ovaries. However, several papers reported that the influence of phytoestrogens on serum hormones is still uncertain (15). In one of these studies, conducted by seven weeks with menopausal rats, the consumption of 5 to $10 \mathrm{~g} /$ day of flaxseed significantly reduced the concentration of estrogen. Lucas et al., 2003 (3) conducted a study for 3 months with menopausal rats fed with $40 \mathrm{~g} /$ day of flaxseed has found a slight increase in estrogen levels, which confirms our results, since the rate was higher and there was a hormonal influence of the seed.

According to literature, flaxseed may produce different results depending on the concentration used and the period of consumption. To date, this is the first study to examine the effects of 25 percent of flaxseed in a diet during menopause and the results that were found corroborate with an earlier study that demonstrated the absence of effects on hormonal levels and on body weight, using different concentrations of flaxseed. This observation is very important, since the benefits of the consumption of phytoestrogen are potential for the health of women and also for the general population. 
Flaxseed is a good option when compared to other phytoestrogens because it presents the largest source of lignans found in nature and its consumption during menopause does not cause damage to health.

\section{Conclusion}

The obtained results show that the intake of 25 percent of flaxseed during menopause influences positively on the reduction of the body weight and serum levels of 17 ß-estradiol, suggesting a positive action in the consumption of seeds during this physiological stage.

\section{References}

1. Canadian Grains Comission. Canada Western Flaxseed an of Yellow Flaxseed Samples. 2001. Disponível em: www. Grainsscanada.dc.ca. Acesso em 10.10.2013.

2. Dodin S, Lemay A, Jacques H, Légare F, Forest J-C, Maassê, B. The effects of flaxseed dietary supplement on lipid profile, bone mineral density and symptoms in menopausal womem: a randomized doube-blind wheat germ placebo-controled clinical trial. J. Clin Endocrinol Metab. 2005;90(3):1390-7.

3. Lucas EA, Lightfoot SA, Hammond LJ, Devareddy L, Khalil DA, Daggy BP, et al. Flaxseed reduced plasma cholesterol and atherosclerotic lesion formation in ovariectomized golden Syrian hamsters. Atherosclerosis. 2004;173(2):223-9.

4. Dalais FS, Rice GE, Walhlqvist ML, Grehan M, Murkies AL, Medley G, et al. Effects of dietary phytoestrogens in postmenopause women. Climateric.1998;1(2):124-9.

5. Morris DH. Essential nutrients and other functional compounds in flaxseed. Nutr Today. 2001;36(3):159-62.

6. Armaganijan D, Batlouni M. Impacto dos fatores de risco tradicionais. Rev Soc Cardiol. 2000;10(6):686-93.

7. Wang L, Chen J, Thompson LU. The inhibitory effect of flaxseed on the growth and metastasis of estrogen receptor negative human breast cancer xenograftsis attributed to both its lignan and oils component. Int J Cancer. 2005;116(95):793-8.

8. Claupach R., Meirelles RMR, Julião MASG, Loureiro CKC, Giarodoli PB, Pinheiro SA, et al. Fitoestrogênicos: Posicionamento do Departamento de endocrinologia Feminina da Sociedade Brasileira de Endocrinologia e Metabologia (SBEM). Arq Bras Endocrinol Metab. 2002;46(6):679-95.

9. Begum NA, Nicole C, Milla I, Lapierre C, Nagano K, et al. Dietary Lignins precursor of mammalian lignans in rats. J Nutr. 2003;134(1):120-7.

10. $\mathrm{Hu} \mathrm{C}$, Yuan YV, Kitts DD. Antioxiant activities of the flaxseed lignan secoisolariciresinol diglucoside, its aglycone ecoisolariciresinol and the mammalian lignans enteroldiol and enterolactone in vitro. Food and Chem Tox. 2007;45:2219-27.

11. Rickets ML, Moore DD, Banz WJ, Mezei O, Shay NF. Molecular mechanism of action of the soy isoflavones includes activation of promiscuous nuclear receptors: a review. J Nutr Biochem. 2005;16(6):321-30.

12. Richard SE, Orcheson LJ, Seidl MM, Luyengi L, Fong $\mathrm{HH}$, Thompson LU. Dose-dependent production of mammalian lignans in rats and in vitro from the purified precursor secoisolariciresinol diglycoside in flaxseed. J Nutr. 1999;126(8):2012-19.

13. Branca F, Lorenzetti S. Health Effects Of Phytoestrogens. Forum Nutr Italia. 2005;57:100-111.

14. Guerra TRB, Boaventura GT, Vellarde CLG. Phytoestrogens the modulador selective receptor estrogen? Rev Bras Pesqui Méd Biol. 2011;10(1):67-70.

15. Hutchins AM, Slavin JL. Effects of flaxseed on sex hormones metabolism. In: Thompson LU, Cunnane SC, editors. Flaxseed in human nutrition. $2^{\mathrm{a}}$ ed. Champaign: AOCS Press; 2003. p. 126-49.

16. Pardridge WM, Mietus LJ. Transport of Steroid Hormones through the Rat Blood-Brain Barrier. J Clin Invest. 1979 Jul;64(1):145-54.

17. Ruggiero R, Likis FE. Estrogen: physiology, pharmacology, and formulations for replacement therapy. J of Midwifery \& Womens Health. 2002;47(3):130-8.

18. Puig-Duran E, Greenstein BD, MacKinnon PCB. Effects of serum o estrogen-binding components on the unbound oestradiol- $17 ß$ fraction in the serum of developing female rats and on inhibition of $[3 \mathrm{H}]$ oestradiol uptake by uterine tissue in vitro. J Reprod Fert. 1979;56(2):707-14.

19. Ghiselli G, Jardim WF. Interferentes Endócrinos no ambiente. Química Nova. 2007;30(3): 695-706.

20. Hulley S, Grady D, Bush T, Furberg C, Herrington D, Riggs B, et al. Randomized trial of estrogen plus progestin for secondary prevention of coronary heart disease in postmenopausal women. JAMA. 1998;280(7):650-13.

21. Tremolliéres FA, Pouilles JM, Ribot CA. Relative influence of age and menopause on total and regional body composition changes in postmenopausal women. Am J Obstet Gynecol. 1996;175(6):1594-600.

22. Buss C, Nunes MA, Camey S, Manzolli P, Soares RM, Drehmer $M$, et al. Dietary fibre intake of pregnant women attending general practices in southern Brazil - the ECCAGE study. Public Health Nutr. 2009;12(9):1392-8.

23. Shoppen S, Acarbajal A, Pérez-Granados AM, Vivas F, Pilar Vaquero M. Food energy and macronutrient intake of postmenopausal women from a menopause program. Nutr Hospitalaria. 2005;20(2):101-9.

24. Botsis D, Christodoulakos G, Papagianni V, Lambrinoudaki I, Aravantinos L, Makrakis E, et al. The effect of raloxifene and tibolone on the uterine blood flow and endometrial thickness: a transvaginal Doppler study. Maturitas. 2006;53(3):362-8. 
25. Biondo-Simôes MLP, Zimmermann E, Daher TS, Borsato KS, de Noronha L. Effects of hormonal replacement therapy on colon anastomosis healing in rats. Acta Cir Bras. 2005;20(3):237-42.

26. Miller O. O laboratório para o clínico. $3^{\mathrm{a}}$ ed. São Paulo: Atheneu; 1977.

27. Mikkola TS, Clarkson TB. Estrogen replacement therapy, atherosclerosis and vascular function. Cardiovasc Res. 2002;53(3):605-19.

28. Jenkins DJ, Kendall CW, Vidgen E, Agarwal S, Rao AV, Rosenberg RS, et al. Health aspects of partially defatted flaxseed, including effects on serum lipids, oxidative measures, and ex vivo androgen and progestin activity: a controlled crossover trial. Am J Clin Nutr. 1999;69(3):395-402.

29. Lemay A, Dodin S, Kadri N, Jacques H, Forest JC. Flaxseed dietary supplement versus hormone replacement therapy in hypercholesterolemic menopausal women. Obstet Gynecol. Sep 2002;100(3):495-504.

30. Lucas EA, Wild RD, Hammond LJ, Khalil DA, Juma S, Daggy BP, et al. Flaxseed improves lipid profile without altering biomarkers of bone metabolism in postmenopausal women. J Clin Endocrinol Metab. 2002;87(4):1527-32

31. Soares LL, Pacheco JT, Brito CM, Troina AA, Boaventura GT, Guzman-Silva MA. Avaliação dos efeitos da semente de linhaça quando utilizada como fonte de proteína nas fases de crescimento e manutenção em ratos. Rev Nutr. 2009; 22(4):483-91.

32. Lissin DV, Gomperts SN, Carroll RC, Christine CW, Kalman D, Kitamura M, et al. Activity differentially regulates the surface expression of synaptic AMPA and NMDA glutamate receptors. Proc Natl Acad Sci USA. 1998;95(12):7097-102.

33. Lemay A, Dodin S, Kadri N, Jacques H, Forest JC. Flaxseed dietary supplement versus hormone replacement therapy in hypercholesterolemic menopausal women. Obstet Gynecol. 2002;100(3): 495-504.

34. Silva MR, Silva MAAP. Aspectos nutricionais de fitatos e taninos. Rev Nutr. 1999;12(1):21-32.

35. Wannmacher L, Reiner RL. Reposição hormonal na menopausa: questáo ainda polêmica. Boletim da Sociedade Brasileira de Vigilância de Medicamentos. 1998;30:5-8.

36. Bhathena SJ, Velasquez MT. Beneficial role of dietary phytoestrogens in obesity and diabetes. Am J Clin Nutr. 2002;76(6):1191-201.

37. Geary N, Asarian L. Cyclic estradiol treatment normalizes body weight and test meal size in ovariectomized rats. Physiol Behav. 1999;67(1):141-7. 